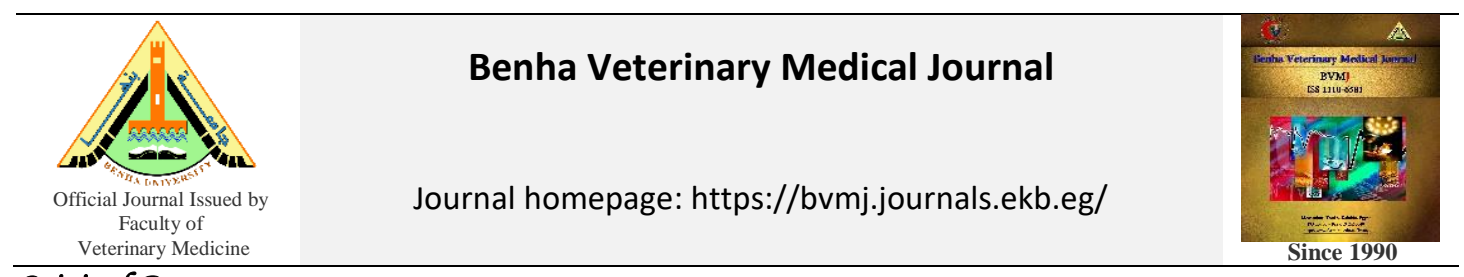

Original Paper

\title{
Molecular detection of novel Bovine Ephemeral Fever Virus strain and its effect on immune system in cattle, Egypt 2017 \\ Rania Abo-Sakaya ${ }^{1}$, and Naglaa M.E.Bazan ${ }^{2}$
}

${ }^{1}$ Department of Animal Medicine, Faculty of Veterinary Medicine, Benha University, Benha, Egypt.

${ }^{2}$ Veterinary Educational Hospital, Faculty of Veterinary Medicine, Benha University, Egypt

\begin{tabular}{l} 
ARTICLE INFO \\
\hline Keywords \\
Bovine Ephemeral Fever \\
RT-PCR \\
Cytokines \\
Inflammatory biomarkers \\
Cattle. \\
\hline Received 31/03/2020 \\
Accepted 30/06/2020 \\
Availa6le On-Line \\
08/09/2020
\end{tabular}

\begin{abstract}
Bovine ephemeral fever (BEF) is an immune related acute febrile disease affecting cattle characterized by expression of inflammatory mediators. This study aimed to clarify immune and inflammatory changes that result from BEF infection in cattle particularly cytokines mechanisms. The study was performed on 100 cattle, 2 - 3 years of age, from endemic areas with three-day sickness in Qaliubiya governorate, Egypt. Characteristic clinical signs appeared on cattle from suspected farms varied from transient fluctuating fever, stiffness, lameness, enlargement of peripheral lymph nodes, decreased milk yield and muscular shivering. So, we performed RT-PCR to confirm the cause of disease by direct detection of the virus targeting glycoprotein coding $(\mathrm{G})$ gene, we found 30 cases positive BEF out of 100 animals. A negative control group was 10 healthy cows that was compared with positive infected group to show effect of virus on immune system by evaluating parameters change by infection, included endogenous pyrogenic variables such as cytokines, Interleukins (IL-2 and IL-6) and inflammatory biomarkers as (cortisone, CRP). Our results demonstrated substantial increase $(\mathrm{P}<0.05)$ in serum concentrations of IL-2, IL-6, cortisone and CRP as well as hypocalcemia in infected animals
\end{abstract}

\section{INTRODUCTION}

Bovine ephemeral fever (BEF) occurs commonly in temperate areas of Africa, Asia, Australia and the MiddleEast and leading to loss of beef and milk production, infertility and abortion (Yoshimasa et al., 2015). The mortality rate is generally low (rarely exceeds $1 \%$ ) although, the morbidity rate is high (up to 100\%) and the most common manifestations are unexpected onset of high fever $\left(41^{\circ} \mathrm{C}\right)$, anorexia, nasal discharge, salivation, sharp drop in milk production, stiffness, ruminal stasis and dyspnea (Walker et al., 2012). Three Day Sickness is another synonym to BEF and defined as an arthropod born viral infectious disease of cattle and water buffaloes caused by genus Ephemerovirus, Family Rhabdoviridae (Degheidy et al., 2011 and Lee, 2019). The seasonal condition of tropical and subtropical parts of the world enhance dispersal of infection, where BEF is endemic there. (Walker, 2005). The infection is branded by noticeable and severe manifestations of the disease such as abrupt onset of high temperature, staggering gait and unwillingness to move (Yoshimasa et al., 2015). The severe environmental stress help the clinical signs to be worsened_(Tsuyoshi et al., 2015). The term three days sickness refers to recovery of infected animals within $72 \mathrm{hrs}$ following the onset of symptoms. The unexpected onset of fever, off food, nasal secretions were observed in infected animals.
Infections with bovine ephemeral fever virus were noticed in 7 governorates in Egypt; during summer seasons in 2006 and 2009 (Degheidy et al., 2011). The latter authors added that Viral identification by indirect immunoflourcent technique showed positive records of $36.6 \%$ from buffy coat and PCR showed 500 bp clear single band and they concluded that IFAT and RT-PCR proved to be rapid, sensitive and specific for BEF VIRUS identification. Barigye et al. (2016) reported that plasma IL-6 and IL-10 were increased in all animals infected with BEF VIRUS starting several days before initiation of viraemia; this increase in plasma IL-6 and IL-10 precedes seroconversion during BEF VIRUS infections in cattle suggesting the two cytokines may influence immunological events that pave way to B-cell activation and seroconversion. The neutralizing antibody was enhaned by the envelope glycoprotein $(\mathrm{G})$, which was acts against experimental encounter in cattle. Neutralizing antigenic determinants were placed in four independent parts (G1-G4) in the $G$ protein (Kato et al., 2009 and Roche et al., 2006). BEF was immune interceded, that the clinical manifestation of the illness were the appearance of inflammation mediators which were responsible for acute febrile diseases. Clinical features and pathological alterations were indications of the virus growth effect and the host's response (Yeruham et al., 2010).

\footnotetext{
* Corresponding author: Dr. Rania Abo-Sakaya, E mail. rania.aboskayah@ fvtm.bu.edu.eg ,Department of Animal Medicine,

Faculty of Veterinary Medicine, Benha University, Benha, Egypt.
} 


\section{MATERIAL AND METHODS}

2.1. Animals

The current study was carried out on 100 cattle, 2 - 3 years of age from different cattle farms situated at Qaliobeya governorate, Egypt. The animal handling procedures in this study were agreed by the team of scientific research ethics (BUFVTM09032020), Faculty of Veterinary Medicine, Benha University, Egypt. The animals suffered from clinical signs including fever, anorexia and nasal discharge that were suggested to be due to BEF infection during the middle of August 2017. In addition, ten cattle were apparantly healthy which were considered as control group. All animals were exposed to clinical inspection as stated by Radostits et al. (2007)

\subsection{Sample collection and laboratory testing}

Two blood samples were obtained from jugular veins of all infected animals. The first sample was collected in sterile tube with sodium citrate as an anticoagulant at an early febrile stage of the disease for separation of buffy coat used as a source for suspected viral samples (Van Der W esthuizen, 1967) for direct detection of the viral nucleic acid using conventional reverse transcription polymerase chain reaction (RT-PCR). The second sample was gathered in tube without anticoagulant for serological examination and left few minutes to obtain serum to estimate some parameters that indicate immune system response to infection as cytokines, Interleukins (IL-2 and IL-6) and inflammatory biomarkers as (cortisone, CRP). The obtained samples were labelled and stored at $-20{ }^{\circ} \mathrm{C}$ till examined.

Serum IL-2 was determined using Bovine IL-2 ELISA kit (Cat. No. MBS2701033, MyBioSource) according to the method described by Gearing and Thorpe (1988) while serum IL-6 was determined using Bovine IL-6 ELISA kit (Cat. No. MBS564191, MyBioSource) according to the method described by Chan and Perlstein (1987). Serum cortisol level was determined using Bovine Cortisol ELISA kit (Cat. No. MBS701325, MyBioSource).

Serum CRP concentration was determined using CRP-Latex commercial kit supplied by SPINREACT, SPAIN, according to the method described by Young (2001)

Serum Calcium concentration was determined using QuantiChrom ${ }^{\mathrm{TM}}$ Calcium Assay Kit (Cat. No. DICA-500, BioAssay Systems, USA).

\subsection{RNA extraction}

RNA of BEF virus was extracted from buffy coat of the 100 examined animals using (QLAamp viral Mini Kit, Qiagen $\mathrm{GmbH}$, Germany). $140 \mathrm{ul}$ of sample suspension with $560 \mathrm{ul}$ AvL lysis buffer and 5.6 uL of carrier RNA were incubated at room temperature followed by adding $560 \mathrm{ul}$ of ethanol $100 \%$. The sample was cleaned and centrifuged according to manufacture recommendations, RNA was eluted using $60 \mathrm{ul}$ elution buffer and stored at $-20{ }^{\circ} \mathrm{C}$ until further PCR analysis.

\subsection{PCR amplification}

Primers were consumed in a $25 \mathrm{ul}$ reaction having 12.5 Quantilect probe rt-PCR buffer (QLAgen, Gmbh). 1ul from each primer (listed in Table 1), $0.25 \mathrm{ul} \mathrm{rt}$ - enzyme, $5.25 \mathrm{ul}$ water and $5 \mathrm{ul}$ DNA templet were mixed and the reaction was performed in Biomerta thermal cycler.

Reverse transcription was performed at $50^{\circ} \mathrm{C}$ for $30 \mathrm{~min}$, a primary denaturation step was followed by 35 cycles of PCR amplification as follow: after the first denaturation at $94^{\circ} \mathrm{C}$ for $5 \mathrm{~min}$, the amplification involving denaturation at $94^{\circ} \mathrm{C}$ for $40 \mathrm{~s}$, annealing at $48^{\circ} \mathrm{C}$ for $1 \mathrm{~min}$, primer extension at $72^{\circ} \mathrm{C}$ for $40 \mathrm{~s}$ and the last extension for $10 \mathrm{~min}$ at $72^{\circ} \mathrm{C}$. PCR products were separated by electrophoresis on $1.5 \%$ agarose gel, read by gel documentation system (alpa innotesh, biometra) and the data evaluated by computer software.

Table 1 Primer sequences of the Target gene amplicon:-

\begin{tabular}{lccc}
\hline Reference & $\begin{array}{c}\text { Length of } \\
\text { amplified } \\
\text { product } \\
\text { (bp) }\end{array}$ & Primer seq. (5-3) & Target gene \\
\hline $\begin{array}{l}\text { Kasem et } \\
\text { al. (2014) }\end{array}$ & $420 \mathrm{bp}$ & AGAGCTTGGTGTGAATAC & $\begin{array}{c}\text { Glycoprotein } \\
\text { (G) gene }\end{array}$ \\
\hline
\end{tabular}

\subsection{Statistical evaluation}

Data were statistically investigated by mean of student " $t$ " test and Chi, Square Analysis (Snedecor and Cochran, 1980).

\section{RESULTS}

3.1. Serological Examination to check immune system response to BEF virus infection

$\mathrm{BEF}$ virus infection resulted in a significant increase in the concentration of endogenous pyrogenic variables such as Interleukins (IL-2 and IL-6) and inflammatory biomarkers as (cortisone, CRP) and decrease in calcium concentration in comparison with the control negative cases as shown in table (2) and this indicates the effect of the virus on the immune system. The obtained data showed that BEF VIRUS-infected animals had a substantial alteration $(\mathrm{P}<0.05)$ in serum concentrations.

\subsection{Molecular detection of BEF virus using RT-PCR} In August 2017, 100 cows from different farms showed decreased activity, anorexia and fever in an endemic area with BEF VIRUS in Qaliubiya governorate and the cases were isolated and the remaining animals were kept under observation. We identified BEF virus in buffy coat samples from 30 cattle of the examined animals from different farms using RT-PCR using primers targeting glycoprotein coding (G) gene. A positive result was obtained with the amplification of a specific product 420 bp (Fig. 1). We believed that our assay would be an essential mean for investigation of $B E F$ VIRUS infection.

\section{DISCUSSION}

Bovine ephemeral fever is a wastefully vital disease in cattle characterized clinically by biphasic fever, off food, lameness and recumbency. Infection is produced by a vector-borne single-stranded RNA virus-bovine ephemeral fever virus and imposes substantial economic damages, mostly due to a drop in milk yield (Aziz-Oberon et al., 2013). Our result recorded a state of hypocalcemia. A clinical hypocalcemia is detectable by reducing plasma calcium (less than 2.1 $/ \mathrm{Lmol} / \mathrm{L}$ ), this was in accordance with Jürgen et al., (2011) who concluded that IL-6 is implicated not only in the stimulation of the immune system but also in regenerative processes as well as in the regulation of metabolism, in the protection of bone homeostasis, and in several neural utilities. 
Table 2 Serological Examination to check immune system response to BEF virus infection

\begin{tabular}{lcc} 
virus infection & & \\
\hline Parameters & Control-ve & Infected animals \\
\hline IL-2 & $0.6833 \pm 0.1073$ & $4.493 \pm 0.6110^{* *}$ \\
IL-6 & $8.300 \pm 0.3554$ & $23.18 \pm 3.451 *$ \\
Cortisone & $11.75 \pm 1.153$ & $39.23 \pm 6.566 *$ \\
CRP & $4.827 \pm 0.8572$ & $23.02 \pm 5.035 *$ \\
Calcium & $10.23 \pm 0.1877$ & $7.571 \pm 0.3244 *$
\end{tabular}

IL-2: positive titer equal or more than 0.56, IL-6: positive titer equal or more than 7.00, Cortisone: positive titer equal to or more than $5.00-25.00 \mathrm{mg} / \mathrm{dl}$, CRP reactive protein: Positive titer equal or more than $6.00 \mathrm{mg} / \mathrm{dl}$, Calcium reference $8-11 \mathrm{mgldL}$.

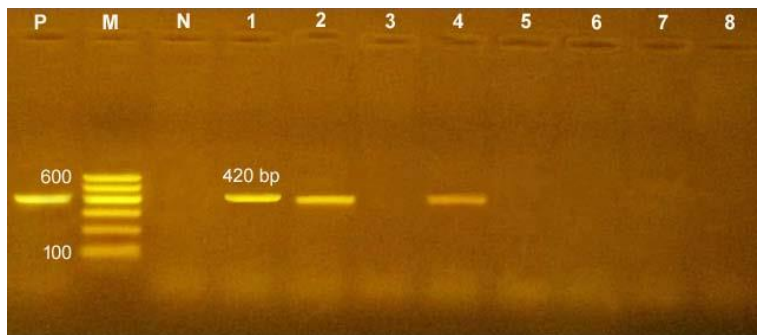

Fig. 1 Electrophoretic pattern of the amplified products $420 \mathrm{bp}$ of the $\mathrm{G}$ gene for BEF viru from blood samples of the infected cattle by RT-PCR. P: Reference BEF virus (Contro positive), M: Nucleic acid marker (100bp), Lanes 1 - 8 : Buffy coat samples from suspected cattle. Lanes 1,2 and 4 were positive samples.

Cytokines are any number of ingredients produced by almost all nucleated cells in the body, particularly immune cells, for example lung macrophages throughout an infection close to pneumonia, immune cells realize a pathogen, or in case of gram- negative organisms, endotoxin created by the pathogen and come to be activated. In cooperation of local and systemic level, stimulated immune cells are necessary to interconnect with one another. Cytokines act to enable intercellular announcement by controlling the animal's reaction to infection, further stimulation of the immune system, inflammation and damage. Our results demonstrated the effect of BEF VIRUS on immune system by measuring parameters of body inflammatory response to infection and compared with healthy animals. Cytokines were increased to defend against virus infection in infected animals. The current study recorded a significant increase in IL-2 and IL6 after $B E F$ VIRUS infection, this result was in agreement with Walker et al. (2012) which concluded that IL-6 in infected animals with BEF VIRUS was significantly increased since the virus affected the immune system and increase cytokines to defend against virus infection. The solitary inflammatory cytokine and the essential mediator of the host reaction to infection is IL-6, which can be calculated in substantial amounts in the circulation throughout fever. It is the major endogenous distributing pyrogen responsible for stimulating CNS mechanisms causing febrile response development throughout illness in fever for the period of infection and inflammation. In the current study, biomarkers of inflammation response (cortisone and protein reaction CRP) were significantly increased in the infected animals than in normal healthy animals because the virus had an inflammatory effect and the increase in a number of cytokines can be anti-inflammatory whereas others specially those encourage illness behavior are pro-inflammatory. This result was in agreement with that stated by Dinarello (2000). The reactivity of pro-inflammatory cytokines is retained by anti-inflammatory cytokines. Therefore, extensive tissue damage was avoided. The Th2 or humoral side of the immune response was responsible for anti-inflammatory cytokines, while pro-inflammatory cytokines were related to Th1 or the cellular immunity of the immune reaction (Elenkov, 2009). During trauma or illness, the concentration of circulating pro-inflammatory cytokine-like IL-6 tends to rise up to $1000 \mathrm{X}$. The inflammation was speeded up by proinflammatory cytokines through initiating the synthesis of cellular adhesion fragments and chemokines that attract and store inflammatory cells such as neutrophils, monocytes, macrophages, and lymphocytes locally at the site of infection (Buhman et al., 2000).

\section{CONCULSION}

The present study concluded that BEF VIRUS affects the immune system resulting in substantial increase $(\mathrm{P}<0.05)$ in serum concentrations of endogenous pyrogenic variables such as cytokines, Interleukins IL-2 and IL-6 and inflammatory biomarkers as cortisone, CRP. On the other hand, calcium concentration was decreased.

\section{ACKNOWLEDGMENT}

We would like to thank all members in the Veterinary Teaching Hospital, Benha University where, the study was performed.

\section{REFERENCES}

1. Aziz-Oberon, O., Leibovitz, K., Gelman, B., Kedmi, M. and Klement, E. (2013). Safety, Immunogenicity and Duration of Immunity Elicited by an Inactivated Bovine Ephemeral Fever Vaccine. PLOS ONE 8(12): e82217. doi:10.1371/journal.pone.0082217.

2. Barigye, R., Melville, L. F., Davis, S., Walsh, S., Hunt, N. and Hunt R. (2016). Kinetics of selected plasma cytokines during innate-adaptive immune response transition in adult cattle infected with the bovine ephemeral fever virus. Veterinary Microbiology, 186 (111-116).

3. Buhman, M. J., Perino, L. J., Galyean, M. L., Wittum, T. E., Montgomery, T. H. and Swingle, R. S. (2000). Association between changes in eating and drinking behaviors and respiratory tract disease in newly arrived calves at a feedlot. Am. J. Vet. Res.;61: 1163-1168.

4. Chan, D. W. And Perlstein, N. T. (1987). Immunology: A practical Guide Eds, Academic Press, New York, P71.

5. Degheidy, N. Sh., Hassan, H. Y., EL-Sanousi, A. A., Salem, S. A., Beshir, E. and Hanan A. El-Sadawy, H. A. (2011). Recent trials for diagnosis of Bovine Ephemeral Fever in Egypt. In proceeding of 15th International Society for Animal Hygiene (ISAH) congress (pp. 447-451). Vienna, Austria.

6. Dinarello, C. A. ( 2000). Proinflammatory cytokines. Chest. 118(2): 503-508.

7. Elenkov, I. J. (2009). Neuroendocrine effects of the immune system. In: Adrenal Physiology and Disease. Geo. Chrousos, ed., EndoText.com : Chapter 28.

8. Gearing, A. J. and Thorpe, R. (1988). The international standard for human interleukin-2. Calibration by international collaborative study, Journal of Immunological Methods, 114, 3-9.

9. Jürgen, S., Athena, C., Dirk, S. and Stefan, R. (2011). The pro- and anti-inflammatory properties of the cytokine interleukin-6 Biochimica et Biophysica Acta 1813 878-888

10. Kasem, S., Dawod, A., Khodier, M., Ktob, A., Abouelyazeed M., Abdel Kareem, S. and Ibrahim, B. (2014). Isolation and characterization of bovine 
Ephemeral fever Virus in Delta provinces Egypt 2012 Global Veterinaria. (13) :972-976.

11. Kato, T., Aizawa, M.,Takayoshi, K., Kokuba, T., Yanase, T., Shirafuji, H., Tsuda, T. And Yamakawa, M - (2009). Phylogenetic relationships of the G gene sequence of bovine ephemeral fever virus isolated in Japan, Taiwan and Australia. Vet. Microbiol. 137:217223.

12. Lee, F. (2019). Bovine Ephemeral Fever in Asia: Recent Status and Research Gaps. Viruses, 11, 412.

13. Radostits, O. M., Gay, C., Hinchcliff, K. W., and Constable, P. D. (2007). A textbook of the diseases of cattle, sheep, goats, pigs and horses. Veterinary Medicine 10th edition Bailliere, Tindall, London, UK, 1576-80.

14. Roche, S., Bressanelli, S., Rey, F. A. and Gaudin, Y. (2006). Crystal structure of the low-pH form of the vesicular stomatitis virus glycoprotein G. Science 313:187-191. 10.1126/science.1127683.

15. Snedecor, G. W. and Cochran, W. G. (1980). Statistical Methods. 7th Edition, Iowa State University Press, Ames.

16. Tsuyoshi, N., Hiroaki, S., Kazufumi, I., Yoshiki, N., Moemi, S., Tomoko, K. and Tohru, Y. (2015). Occurrence of bovine ephemeral fever in Okinawa Prefecture, Japan, in 2012 and development of a reverse-transcription polymerase chain reaction assay to detect bovine ephemeral fever virus gene. J. Vet. Med. Sci. 77(4): $455-460$.

17. Van Der Westhuizen, B. (1967). Studies on bovine ephemeral fever Isolation and preliminary characterization of a virus from natural and experimentally produced cases of bovine ephemeral fever. Onderstepoort J. Veterinary Research, 34: 29-40.

18. Walker, P. J. (2005). Bovine ephemeral fever in Australia and the world. Microbiol Immunol Journal. ;292 : 57-80.

19. Walker, P. J., Blasdell, K. R. and Joubert D. A. (2012). Ephemeroviruses: arthropod-borne rhabdoviruses of ruminants, with large and complex genomes. In Dietzgen RG, Kuzman IV (ed), Rhabdoviruses: molecular taxonomy, evolution, genomics, ecology, cytopathology and control. Horizon Scientific Press, Norwich, CT.

20. Yeruham, I., Van Ham, M. and Braverman, Y. (2010). Epidemiological Investigation of Bovine Ephemeral Fever Outbreaks in Israel. Vet Med Int. 2010: 290541.

21. Yoshimasa, H., Mariko, N., Yoshiro, O., Tomoko, K., Hiroaki, S., Mitsuteru, K., Toyoshige, I. and Tohru, Y. (2015). Resurgence of bovine ephemeral fever in mainland Japan in 2015 after a 23-year absence. Journal of Veterinary Medical Science. 79(5):904-911.

22. Young, D.S. (2001). Effect of disease on clinical lab. Tests, 4th Ed AACC. Randomized, controlled trial, Hepatology. 32: 135-138. 